\title{
Lutas sociais e Serviço Social: sobre sementes e frutos
}

\author{
Mas é nelas (bocas e mãos, \\ sonhos, greves e denúncias) \\ que te vejo pulsando, \\ mundo novo, \\ ainda que em estado de soluços \\ e esperança. \\ Ferreira Gullar
}

As ruas explodem no Brasil em rebeldia e indignação surpreendendo àqueles que acreditavam na paz das aparências, desconsiderando as contradições que germinavam sob o manto ideológico do transformismo e da cooptação.

Os protestos que se alastram marcarão uma nova fase da conjuntura brasileira, mas, certamente, trazem um fenômeno muito conhecido para aqueles que estudam nossa sociedade na perspectiva das lutas sociais e não se renderam à sedução pós-moderna da fragmentação e do elogio à aleatoriedade.

As diferentes manifestações particulares das contradições da ordem capitalista que se expressam na exploração do trabalho, na opressão que marca as relações entre homens e mulheres, no racismo, na destruição ambiental, na homofobia, nas condições de moradia, na ocupação do espaço urbano e tantas outras, ao contrário de negar a força estruturante da sociedade do capital comprova sua plena generalização.

Nunca como hoje foi tão necessária a categoria de totalidade, no entanto não nos basta sua mera afirmação contra as pretensões de um pensamento voltado ao particularismo do acontecimento preso à pseudoconcreticidade dos fenômenos. A totalidade é sempre um universal vazio se não compreendida como movimento que o leva até o universal concreto por meio das particularidades que o compõe.

A luta de classes que brota das contradições fundamentais da ordem do capital se expressa em uma diversidade de formas para as quais nem sempre é tão simples estabelecer os nexos com o todo. Como já disse Lukács, não é o filósofo que coloca estas contradições no mundo, portanto, não pode lançar um olhar arrogante sobre as pequenas lutas do mundo e as desprezar.

Em se tratando do Serviço Social, o nexo que liga as diversas formas particulares das contradições de nossa época histórica e as determinações mais gerais que se encontram em sua base, torna-se algo de essencial. Não apenas pelo fato de que assim se materializa o objeto central de nossas reflexões, a chamada "questão social", mas porque queremos compreendê-la na dinâmica da luta de classes e na perspectiva da emancipação.

Os movimentos e lutas sociais encontram-se exatamente na tensão que marca os limites e possibilidades desta emancipação. Todas nossas lutas tem que obrigatoriamente se dar no interior de uma determinada ordem, seja na forma das relações sociais de produção dominantes, seja nas formas políticas e jurídicas que são suas expressões, assim como no interior de uma certa forma de consciência social que lhes corresponde. Mesmo aqueles que lutam revolucionariamente contra o estabelecido querendo buscar os caminhos radicais de sua superação não tem outro meio que não construir o futuro com os materiais que encontramos em nosso presente.

Para o Serviço Social que afirma seu compromisso ético-político no horizonte da emancipação humana esta é uma questão das mais importantes: como atuar nas lutas no interior da ordem que se limita, e, por vezes, está mesmo aquém da mera emancipação política, sem perder a meta da emancipação humana?

Assim, para nós, mais do que marcar a diferença substancial entre uma luta social nos limites da ordem existente e aquelas que apontam para a sua superação, nos interessa o movimento real que leva de uma a outra. A mediação fundamental deste movimento se encontra no cotidiano. É nele que vivemos as relações que materializam a ordem da mercadoria e do capital, nascendo em uma determinada forma de família, educando 
as crianças, estabelecendo hierarquias de sexo e idade, vendendo nossa força de trabalho, mediando nossas necessidades por equivalentes monetários, morando em nossas casas cuja arquitetura expressa desde a profunda individualização do ser social até a massificação reificada da cidade e sua opressão, sua violência, sua cinzetude carrancuda, mas também sua resistência nas cores dos grafites, na ironia que ri de nossa condição transformando dor em riso, na festa, na luta. É no cotidiano que vivemos as condições que nos levam à reificação e as contradições que podem nos levar à emancipação.

As sementes da resistência são lançadas pelos opressores e, não raramente, pelas ações que pretendiam evitá-la. Somos agricultores da revolta, mas trabalhamos nos campos que não são nossos. As sementes germinam em solidão, regadas pelas lágrimas da dor, aquecidas pelo sol da raiva contida, contidas pela força da terra que nos oprime. Presa a este momento, uma teoria social só poderia ser uma antropologia do sofrimento, da resistência muda e contida, da adaptação ou da mera resistência: como vivem os trabalhadores submetidos à exploração, as mulheres à opressão, como vivem os negros sob o racismo, como vivem os pobres em sua invisibilidade visível?

Entramos na terra para ver melhor as sementes e podemos perder de vista o campo semeado. Mesmo quando brotam, se elevam acima da terra que as oprimia, cuidamos de folhas pequenas e frágeis caules que timidamente se erguem apenas para ser ceifados e colhidos para a ordem da mercadoria ou pela prepotência do Estado que a representa.

Uma luta social é expressão de um ser social que foi subsumido à serialidade reificada e individualizante que os fez crer que nossa dor é sua dor, que nossa raiva é apenas sua raiva, que nosso destino é sua sina pessoal; e que, em certas condições, é capaz de ver seu próprio sofrimento no sofrimento do outro, sua revolta na luta de outros. Indivíduos que nunca deixaram de ser um ser social, mas que agora, diante de uma injustiça ou uma opressão particular, podem superar o campo prático inerte em que se inseriam e chamavam de realidade, por meio de uma ação conjunta que pode se converter em práxis livre.

Estamos convictos que não apenas indivíduos podem encontrar novamente seu ser social no corpo de um movimento ou luta social, mas mesmo estes movimentos particulares diante de uma ameaça universal podem encontrar seu ponto de fusão na ação de massas e, em condições muito específicas, sua fusão de classe.

Jovens se levantam contra o aumento das passagens e logo enfrentam a prepotência da ordem. Prefeitos dizem que não abaixarão as tarifas, governadores mobilizam suas tropas de choque, presidentas e congressos fingem pateticamente não ser com eles e... pronto, cada um vai à rua com sua própria revolta e indignação, potencializados mas não produzidos pelas redes sociais, e, de repente, somos todos jovens, todos mulheres, todos negros, todos pobres, todos trabalhadores... fusão: a rebeldia deles se tornou a minha, minha revolta tornou-se a nossa revolta.

Ainda heterogêneo, diverso, múltiplo, mas a ameaça comum aponta para alvos comuns e precisos: os governos federal, estaduais e municipais e seus personagens e símbolos, palácios, assembleias, tribunais; mas, também, os bancos, os templos do consumo, os pedágios, a polícia. Uma homogeneidade heterogênea, uma unidade na diversidade antes fragmentária... uma luta social de massas que ainda não aflorou sua fusão de classe. Para esta não basta a revolta, não basta a miséria, como diziam Marx e Engels, é necessário a miséria consciente de sua miséria e para isso o desvelar das determinações mais profundas e a intencionalidade de classe por traz das diversas formas de opressão e exploração.

É preciso que esta ameaça ganhe rosto e nome - industriais, banqueiros, empreiteiros, grandes monopólios do comércio, o agronegócio, os donos dos meios de comunicação, a máfia dos planos de saúde, os mercadores da educação -, ou seja, a grande burguesia monopolista. Só quando definimos nitidamente "eles" é que toma forma o "nós": proletários. E a meta da emancipação humana começa a tomar forma. Mas, como buscá-la, quando será possível alcançá-la, quais as formas de organização necessárias, quem será seu sujeito? Uma classe que se pergunta isso, já começou a construir suas respostas.

As sementes brotaram e, porque são gente e não planta, levantam suas raízes do chão, caminham e lutam, e começam a ver além dos horizontes impostos, se descobrem a si mesmo no outro que luta a seu lado, se apaixonam e amam.

Ainda é cedo, olhamos para eles com o orgulho de nossas mãos cansadas pelo cultivo, acenamos e os saudamos. É tempo de colheita, não temos tempo de sentir o cansaço que o corpo reclama. Ainda é cedo, muito temos que fazer, mas temos uma certeza: eles carregam nossos frutos.

Mauro Luis Iasi, Rio de Janeiro, julho de 2013. 


\section{Mauro Luis Iasi}

Professor Adjunto da Escola de Serviço Social da Universidade Federal do Rio de Janeiro (ESS/UFRJ) Núcleo de Estudos e Pesquisas Marxistas (Nepem)

Núcleo de Educação Popular - 13 de Maio

\section{UFRJ - Escola de Serviço Social}

Av. Pasteur, 250

Campus Praia Vermelha

Rio de Janeiro - Rio de Janeiro - Brasil

CEP: $22290-240$ 